\title{
Dois dogmas do lulismo
}

Vinicius Gomes Lobo'

\section{Resumo}

Defendo neste ensaio que a gestão do presidente Lula foi socioeconomicamente condicionada por dois dogmas. Um deles foi a expansão extensiva e intensiva da demanda efetiva, implementada sobretudo através do programa Bolsa Família e da política de valorização real do salário mínimo. E o outro, defendido de maneira puramente interpretativa, uma política de livre desenvolvimento ideológico do ideal monetário-mercantil. O texto é dividido em três seções. Na primeira, faço uma breve apresentação do marco teórico que orientará a análise da gestão do presidente Lula: a teoria da reprodução de Rosa Luxemburgo, exposta em $A$ acumulação do Capital. Na segunda, tento analisar, a partir da perspectiva da reprodução, o modelo lulista de acumulação de capital. E, por fim, na terceira, tento apontar alguns possíveis impactos ideológicos desse modelo.

Palavras-chave: Reprodução. Acumulação. Mercadoria. Desenvolvimento. Trabalho.

Meu amigo e minha amiga, não tenha medo de consumir com responsabilidade. Se você está com dívidas, procure antes equilibrar seu orçamento. Mas, se tem um dinheirinho no bolso ou recebeu o décimo-terceiro, e está querendo comprar uma geladeira, um fogão ou trocar de carro, não frustre seu sonho, com medo do futuro. Se você não comprar, o comércio não vende. E se a loja não vender, não fará novas encomendas à fábrica. E aí a fábrica produzirá menos e, a médio prazo, seu emprego poderá estar em risco. (Luiz Inácio Lula da Silva, dezembro de 2008, em mensagem de fim de ano vinculada em emissoras de TV e rádio.)

\section{Introdução}

Este artigo tentar fazer uma análise da experiência econômica vivida durante o governo do ex-presidente Lula a partir da teoria da reproduçáo de Rosa Luxemburgo. Seu entendimento particular do fenômeno da reproduçáo é algo que permite relacionar adequadamente alguns fatores chaves da realidade econômica nacional recente, tais como: superávits comerciais, política social, informalidade e desemprego estrutural, aumento da demanda agregada

I Mestre em Sociologia pela Universidade Federal de Pernambuco (UFPE) Recife, Brasil.. É autor de artigo publicado na revista Estudos de Sociologia (Recife) (2012) e de um dos capítulos do livro A arte brasileira (Recife) (20II). E-mail: viniciuslobo87@gmail.com. 
e crescimento. Espero, assim, expor como tal teoria é um elemento explicativo essencial à compreensáo do que vem acontecendo com a economia brasileira nos últimos anos.

O texto é dividido em três seçóes. Na primeira, faço uma breve apresentaçáo do marco teórico que orientará a análise da intervenção lulista: a teoria da reprodução das condiçóes de produção, de Rosa Luxemburgo, exposta em sua obra $A$ acumulaçáo do Capital. Na segunda, intento analisar, a partir da perspectiva da reprodução e de um "feijão com arroz econômico", o modelo de acumulaçáo de capital da gestáo do presidente Lula. E, por fim, na terceira, tento apontar alguns possíveis impactos dessas mudanças econômicas sobre o ambiente ideológico da sociedade brasileira.

O presente ensaio almeja ser apenas um estudo introdutório à história recente da acumulaçáo de capital no Brasil. A concreta compreensão da nova fenomenologia do capitalismo brasileiro e dos resultados culturais de tal nova composiçáo requerem um estudo muito mais aprofundado do que o presente.

\section{A propósito das condições de reprodução do capital}

A investigação de Marx sobre o problema da reproduçáo do capital social total é uma das contribuiçóes perenes do autor à Economia Política. Apesar de, nas duas primeiras décadas do século XX, ter havido um intenso debate sobre o assunto, principalmente entre pensadores russos e alemáes, a forma dominante através da qual o problema da reproduçáo das condiçóes sociais do capitalismo foi teoricamente abordado no último quarto do século dependeu, fundamentalmente, da contribuiçáo de dois franceses: Louis Althusser e Pierre Bourdieu. A grande contribuição do primeiro é sem dúvida seu artigo Ideologia e Aparelhos Ideológicos de Estado, publicado pela primeira vez na revista La Pensée, em 1971, enquanto o trabalho que colocou Bourdieu em evidência como teórico da reproduçáo foi seu o livro $A$ Reproduçáo: elementos para uma teoria do sistema de ensino, também publicado em 1971, além de quase toda sua obra posterior. Ambos os autores colocam a educaçáo no centro da dinâmica do fenômeno reprodutivo, e nesse sentido, mesmo trilhando caminhos diferentes, desenvolvem uma abordagem similar². Proponho, entáo,

2 Tal similitude é também defendida por Dermeval Saviani, o qual afirma que as concepções educacionais de Bourdieu e Althusser, por serem compreendidas dentro do processo de reprodução capital, podem ser 
que, ao falar dessa contribuiçáo francesa, falemos de um modelo político-pedagógico. Por mais que na última seção deste texto eu volte a dialogar com alguns conceitos importantes a essa perspectiva, tal abordagem náo parece ser suficiente para compreender a particularidade dos fatores que motivaram a dinâmica reprodutiva do capital no Brasil durante o Governo Lula.

Todo brasileiro minimamente informado está cansado de ouvir que, nos últimos dez anos, houve um processo de crescimento e distribuiçáo da renda nacional, do qual resultou a metamorfose social favorita do marketing político oficial: a ascensáo de cerca de 30 milhóes de pessoas à classe média. Como espero que fique claro adiante, a natureza da intervençáo lulista no processo de reprodução das condiçóes de produçáo do capital assume, fundamentalmente, uma forma econômica. Isso significa que, na ordem do dia da agenda governista, estavam elementos econômicos intrínsecos à essência particular do processo produtivo nacional, da sua forma peculiar de socialmente produzir os bens $\mathrm{da}$ subsistência humana, o que acredito estar além do alcance teórico do modelo político-pedagógico francês. Assim, a gestâo das condiçóes de reprodução da produçáo material, durante o governo do presidente Lula, esteve, essencialmente, enfocada em fatores econômicos, e náo em fatores ideológicos e culturais.

E no que diz respeito à forma particular que assumiu a gestão da reproduçáo no período em análise, acredito ser importante retomar uma das primeiras contribuiçóes ao problema do século passado, a de Rosa Luxemburgo, presente em sua obra A Acumulaçáo do Capital. A profundidade ontológica que alcança Luxemburgo, em sua imersáo na essência do movimento acumulativo, leva-a a extrair conclusóes táo densas sobre as condiçóes de reprodução capitalísticas que jamais aparentariam ter seus quase 100 anos de vida. O problema da reprodução das condiçóes de produçáo é abordado, socioeconomicamente, através de uma interpretaçáo crítica do modelo proposto por Marx no segundo volume de $O$ Capital, na qual Luxemburgo elabora conceitos que náo só ajudam a visualizar o atual desenvolvimento da acumulação capitalista na

classificadas como crítico-reprodutivistas (SAVIANI, I99I, p. 90). Por mais que tracem caminhos distintos em suas teorias da reprodução, ambas as perspectivas atribuem protagonismo à instituição escolar. Ambas conferem, portanto, a mesma centralidade da educação como fundamento social do fenômeno da reprodução capitalista, e é nesse sentido que se coloca aqui a semelhança. Sem dúvida, tal proximidade foi determinante para que, nos anos 60, Althusser convidasse Bourdieu para lecionar École Normale Supérieure (ALTHUSSER, 2008, p. 19). 
sociedade brasileira como também os rumos históricos que, em escala global, vêm se desenhando para esse modo de produção. Compreendamos, entáo, em que consiste o problema da reproduçáo do capital social total para Rosa Luxemburgo.

Tomada literalmente, a reproduçáo é simplesmente a repetição ou renovaçáo do processo de produção, e isso é válido para qualquer modo de produçáo. Contudo, se à possibilidade de retomada náo se apresentasse um determinado conjunto de condiçóes, tal fenômeno náo constituiria um problema social e não se teriam gasto tantas linhas com sua reflexão. Garantir as condiçóes propícias à possibilidade da renovaçáo da produçáo é, portanto, o problema central da reprodução em qualquer formaçáo social. Basicamente, em todas as formaçóes produtivas anteriores ao capitalismo, a reproduçáo das condiçóes de produção era voltada à renovaçáo do consumo regular, à nova satisfação das diferentes necessidades da sociedade; e as condiçóes dessa renovaçáo eram, fundamentalmente, a disponibilidade de meios de produçáo (matérias-primas e ferramentas) e de força de trabalho, estando a primeira vinculada ao desenvolvimento da técnica e a segunda, à forma específica das relaçóes sociais de produçáo. Segundo Luxemburgo, nessas formaçóes sociais, somente circunstâncias externas, como guerras ou epidemias, que ocasionariam o "[...] extermínio da população e, com isso, uma destruição em massa de mão de obra ou dos meios de produção estocados, costumavam levar à interrupção da produção ou sua retomada em menor escala." (LUXEMBUGO, 1988a, p. 8). Contudo, no modo de produçáo capitalista, a possibilidade da retomada produtiva se assenta em condiçóes distintas: o início da reproduçáo, nesse caso, não depende apenas da disponibilidade de meios de produçáo e de máo de obra, "[...] depende, sobretudo, do fato de se fabricarem táo-somente produtos cuja perspectiva de realizaçáo seja certa, isto é, que possam ser trocados por dinheiro." (LUXEMBURGO, 1988a, p. 9).

Um modo de produção cuja realizaçâo da empresa produtiva consiste numa troca por dinheiro, isto é, cujo fim do seu desenvolvimento náo é o consumo de determinado produto, mas a posse de uma soma em dinheiro elemento que, como expóe Marx no primeiro capítulo do Capital (2011), é completamente desprovido de valor material - obviamente responderá, na sua retomada, a um imperativo completamente diferente daquele no qual a finalidade era a satisfação das necessidades. O lucro, que, como veremos a seguir, 
trata-se de um fenômeno que só se torna socialmente real quando passa da forma-produto à forma-dinheiro, é o fator determinante não só da produção como também da reproduçáo capitalista, de modo que estabelece náo só os meios e os fins da produção imediata como também define a proporção do novo processo. Assim, enquanto nas outras formaçóes sociais a reproduçáo se define de forma regular e ininterrupta, pois se volta à satisfação das necessidades da comunidade, a reproduçáo capitalista, voltada à prospecçáo cada vez maior de mercados que realizem seus lucros, se apresenta sob a forma de expansóes contínuas sucedidas por uma contraçáo (conjuntura de crise) a partir da qual uma nova ampliaçáo contínua se inicia (LUXEMURGO, 1988a, p. 10). A satisfação da comunidade náo exerce qualquer influência nesse modo de produção, sua finalidade é arrecadar, cada vez mais, uma maior quantia de dinheiro, o que, chegado certo ponto, levará a empresa a ter de ir além da imediatez do seu escopo comunitário inicial. Por ser o lucro a finalidade da produção capitalista, a reprodução assume aí uma tendência expansionista jamais obervada em nenhum outro modo de produção. Contudo, a ampliação da produçáo, e consequentemente do lucro, não depende apenas da cobiça capitalista e da disponibilidade dos meios de produçáo: a realizaçáo dessa ampliação, e aí está o problema propriamente dito da reprodução no capitalismo, depende, fundamentalmente, do seu consumo, isto é, de que haja indivíduos dispostos a oferecer dinheiro em troca desse contingente extra de produtos que é posto em circulação. Assim, a reprodução capitalista, ao ter como finalidade a obtençáo de lucro, tende a configurar-se como reproduçáo ampliada; contudo, como acabamos de observar, a efetividade dessa ampliaçáo é completamente dependente de um demanda monetária que a realize. Observemos, então, com um pouco mais de cuidado, quais são, de forma geral, dentro do modo de produção capitalista, os fundamentos sociais dessa dependência.

Uma inferência que já pode ser feita aqui, a partir da dependência do consumidor da qual padece o empresário capitalista, é que a particularidade histórica da produçáo no capitalismo, ou seja, a questáo de estar sua produçáo voltada a uma finalidade abstrata ou náo material, decorre, mormente, do fato de, nesse modo de produção, a circulação de bens se manifestar através da troca. O desenvolvimento da divisáo do trabalho, ao mesmo tempo em que acarretou um considerável aumento da produtividade, fortaleceu a necessidade de trocar produtos, pois, já que cada produtor focava-se num elemento específico da produção social, não havia como produzir os demais bens necessários à sua 
subsistência. Adam Smith foi um dos primeiros a observar o peso da circulação mercantil sobre o ambiente da produçáo: afirma, em sua Investigação sobre a natureza e as causas da riqueza das naçóes (1974), que "é a certeza de poder trocar o excedente de sua produçáo pelo excedente da produçáo dos outros homens que leva cada homem a dedicar-se a uma única tarefa." (SMITH, 1974 , p. 20). Contudo, sua visáo de mundo burguesa, que o leva a ver na disposição para a troca uma tendência da natureza humana (SMITH, 1974, p. 19), e sua incapacidade de perceber o significado econômico que deriva do fato de a força de trabalho assumir a forma de mercadoria, o levaram a subdimensionar as consequências reprodutivas da circulaçáo mercantil. Mas náo percamos o foco, o que importa, neste parágrafo, é explicitar como o circuito fenomenológico de realização do lucro depende da troca, a fim de que fique claro o papel da demanda na reprodução do capital. Até hoje nenhuma obra expôs táo claramente a essência de uma circulaçáo fundamentada na troca como O Capital. Nessa obra, a troca é o fenômeno escolhido por Marx para ser a porta de entrada para a compreensão do modo de produção capitalista: dedica seu primeiro capítulo a expor que a forma que deve assumir todo produto feito para ser trocado é a de mercadoria. Ser mercadoria, essencialmente, significa poder expressar-se numa substância diferente da sua particular (MARX, 2011, p. 59), fato que claramente se apresenta como fundamental numa relaçáo de troca, já que as identidades (valores de uso) de cada produto específico não sáo suficientes para determinar uma justa proporçáo à permuta. Essa outra substância, através da qual os produtos entáo se expressam, é justamente a do valor, que, como se sabe desde Smith, tem por conteúdo a quantidade de tempo de trabalho. É, portanto, através da quantidade de tempo de trabalho que contém, que um produto se coloca em relaçáo com os outros e entra no mercado. Em outras palavras, quando reconhecido pelo tempo de trabalho que carrega em si, e náo pelo valor de uso da sua propriedade material imediata, é que um produto se expressa como mercadoria e passa a ter valor. E, nesse sentido, o dinheiro nada mais é que o objeto cuja identidade material serve como representante universal do valor, cuja função não é outra senáo a de poder expressar diferentes grandezas de valor (MARX, 2011, p. 91). Essa qualidade específica passa a representar a pura substância social do valor: quantidade de tempo de trabalho. O preço de uma mercadoria, portanto, nada mais é que sua magnitude de valor (tempo de trabalho) expressa na forma-dinheiro. 
É, por conseguinte, a este elemento semiológico específico, a forma-dinheiro, em consequência direta do fato de a circulaçáo efetivar-se através do mercado, e de o trabalho ser dividido, ao qual precisa chegar o processo de produçáo capitalista, a fim de que possa realizar o lucro almejado: "o produtor, que náo produz apenas mercadorias, mas capital, precisa antes de tudo produzir mais-valia. A mais-valia é a meta final e mola propulsora do produtor capitalista." (LUXEMBUGO, 1988a, p. 11). O que leva o produtor capitalista a arriscar colocar em movimento uma quantia de sua forma-dinheiro particular, valor preciosamente entesourado, é a perspectiva de que, ao final do movimento, ele recupere essa exata quantia investida somada a um excedente, que é o lucro ou mais-valia (MARX, 2011, p. 181). Tal recuperaçáo é impossível caso o ponto de chegada da produção, passadas todas as suas metamorfoses, náo seja qualitativamente idêntico ao ponto de partida ${ }^{3}$. Se o circuito náo se completa com a venda das mercadorias, todo movimento foi em váo e o valor originalmente antecipado deixa de ser um investimento para se transformar em gasto. Contudo, devido aos ganhos de capital que o processo produtivo acarreta, mesmo com os riscos envolvidos, qualquer oportunidade de venda é imediatamente abraçada por aqueles que detêm o poder de empresa capitalista, e, na grande maioria das vezes, tal oportunidade aparece como expansão do próprio ramo produtivo com o qual já trabalha a empresa. Essa expansão da produção é justamente a expressão da reprodução ampliada que é típica do capitalismo, no qual a motivaçáo pelo lucro engendra um desejo permanente de retomada da produçáo em proporçáo sempre maior que a anterior. Como bem coloca Marx: "O capitalista só possui um valor perante a história e o direito histórico à existência enquanto funciona personificando o capital [...]. Ao personificar o capital, o que o impele náo são os valores de uso de sua fruiçáo e sim o valor de troca e sua ampliaçáa” (MARX, 1980, p. 688). $\mathrm{O}$ fenômeno que permite a expansão da reprodução é o da acumulação, que é a transformação de parte da mais-valia líquida obtida no período produtivo anterior em capital ativo, isto é, em mais meios de produçáo ou máo de obra. Acumulaçáo significa o uso do lucro para o aumento da capacidade produtiva.

3 "Como agente que subjuga esse processo em que assume e abandona alternadamente a forma dinheiro e a forma mercadoria, conservando-se nessas mudanças, precisa o valor, antes de tudo de uma forma autônoma em que se verifique sua identidade. E essa forma encontra ele apenas no dinheiro. Este constitui, por isso, o ponto de partida e o ponto de chegada de todo processo de expansão do valor." (MARX, 2009, p. 185). 
Como nos diz Luxembugo: "para o capitalista individual, a ampliaçáo da produção se expressa pelo acréscimo de parte da mais-valia apropriada ao capital, ou seja, ele acumula. Acumulaçáo ou transformaçáo da mais-valia em capital ativo é a expressão capitalista da reproduçáo ampliada." (LUXEMBURGO, 1988a, p. 13). A acumulaçáo, portanto, é o meio da reprodução ampliada.

A acumulaçáo, por conseguinte, que consiste na transformação de parte da mais-valia em capital produtivo (meios de produção ou força de trabalho), é a forma peculiar da reproduçáo no capitalismo ${ }^{4}$. Essa expressáo da reprodução ampliada como acumulação de capital é algo que, desde a publicação do segundo volume de $O$ Capital, não é novidade para a Economia Política. No vigésimo terceiro capítulo, Marx discute bastante o processo de conversáo de mais-valia em capital (MARX, 1980, p. 674). Contudo, Luxemburgo apontará uma lacuna no esquema da reproduçáo desenvolvido por Marx, a qual consiste justamente na forma como este último compreende as circunstâncias que determinam a ampliaçáo da reproduçáo, ou seja, o já mencionado problema de quem realiza o lucro do produtor, de quem sáo os compradores do mais-produto decorrente da acumulaçáo que expande a produção. No início do segundo volume de $A$ acumulação do Capital, Luxemburgo afirma:

O esquema da acumulação de Marx não oferece nenhuma resposta à questão do destinatário, ou seja, da pessoa para quem se realiza efetivamente a acumulação. Tomando-se esse esquema ao pé da letra, do modo como foi desenvolvido no fim do volume II [do Capital], ele nos dá a impressão de que cabe exclusivamente à produção capitalista a realização da mais-valia total e que ela utiliza a mais-valia capitalizada para satisfazer a suas próprias necessidades. (LUXEMBURGO, 1988b, p. 5).

Para Luxemburgo, no esquema de Marx para a reprodução ampliada, a soluçáo para o problema sobre a origem da expansáo da demanda que deve realizar o mais-produto decorrente da acumulaçáo é dada pela própria acumulação. É como se a própria ampliação da produçáo fosse a responsável pelo consumo das novas mercadorias. Contudo, se o responsável pela nova demanda é alguém que, no período produtivo anterior, já estava inserido no mercado, como é o caso, por exemplo, de um produtor de sapatos que compra mais couro pra ampliar sua próxima produçáo, o volume monetário em circulação não se altera caso não haja novos compradores, externos à composição

4 Ou, como diria Marx, "[... é é vocação histórica do periodo burguês [...]" (MARX, 1980, p. 692). 
regular do mercado, para os sapatos, pois, sem estes novos clientes, os novos sapatos não podem realizar-se em dinheiro, e, sem essa expansão da demanda, o máximo que pode acontecer é uma transferência de renda dos produtores de sapato para os produtores de couro. Assim, segundo Luxemburgo, "para que a acumulação se verifique é necessário encontrar outros compradores [...] esses compradores devem ter meios próprios de compra, meios que sejam fornecidos por fontes próprias e perfeitamente autônomas." (LUXEMBURGO, 1988b, p. 111). Caso contrário, não há porque expandir a produçáo, pois se não há alteraçáo no volume de riqueza total em circulaçáo, náo há disponibilidade de novo dinheiro, logo, não há novos pontos de chegada disponíveis para o movimento da produção expandida. E para Luxemburgo (LUXEMBURGO, 1988b, p. 115), o esquema de Marx chega a essa soluçáo espúria, que não responde ao problema da realizaçáo do mais-produto decorrente da acumulaçáo, porque concebe a sociedade como sendo única e exclusivamente formada pelo modo de produçáo capitalista. Marx sabia que a expansáo constante da reprodução, ou seja, a acumulação constante de capital, encontra-se ligada a uma expansão igualmente constante da procura monetária, e ele expressa esse fato em diversas passagens do Capital, como, por exemplo, nesta passagem da introduçáo ao sétimo capítulo do volume I: "Condiçáo primeira para a acumulação é que o capitalista tenha conseguido vender suas mercadorias e conseguido reconverter em capital a maior parte do dinheiro assim obtido." (MARX, apud LUXEMBURGO, 1988b, p. 141). Contudo, não foi capaz de perceber que a reprodução ampliada depende da incorporação de novas fontes de renda ao mercado, nova renda esta que é impossível de existir numa sociedade caso todos os seus membros já estejam integrados à dinâmica da produção capitalista. Daqueles que já estão integrados ao círculo fechado da produçáo capitalista náo pode vir, portanto, a procura monetária excedente. Luxemburgo defende, então, que a reprodução capitalista precisa, portanto, de "terceiras pessoas", de outras fontes monetárias além daquelas dos agentes imediatos envolvidos na produçáo. A expansáo do capitalismo, portanto, náo pode prescindir da existência concomitante de sociedades ou camadas sociais não-capitalistas. Para ela, esse é o "ponto nevrálgico do problema da acumulação” (LUXEMBURGO, 1988b, p. 25). Luxemburgo, então, afirma que essas outras formaçóes sociais são o meio histórico para o desenvolvimento global do capitalismo, e, na medida em que presenciava a corrida neocolonialista da Europa no início do século XX, defenderá que é o imperialismo a solução para o problema da acumulaçáo capitalista. 
Contudo, por mais que se aceite a tese de Luxemburgo segundo a qual a reproduçáo capitalista depende de sociedades ou camadas sociais náo-capitalistas, náo podemos aceitar que seu desenvolvimento ainda se dê sob a forma de imperialismo, pelo menos náo como neocolonialismo. Nesse sentido, para que a abordagem de Luxemburgo sobre o problema da reproduçáo no capitalismo possa contribuir à compreensão do presente, é preciso colocá-la em contato com as soluçóes contemporâneas que a tal problema vêm sendo apresentadas. É preciso, portanto, conhecer os novos mecanismos através do quais o império da produçáo capitalista vem ocupando espaços. Acredito, por conseguinte, que a experiência de crescimento econômico vivida pelo Brasil durante o Governo Lula pode ser compreendida como um tipo de soluçáo contemporânea para o problema da reproduçáo. Penso que tal experiência pôs em vigor um método específico de acumulação. Vejamos, então de uma vez, como as medidas levadas a cabo pelo Governo Lula se enquadram como soluçóes ao problema da reproduçáo, tal qual ele é concebido na teoria da acumulação do capital de Rosa Luxemburgo.

\section{0 significado reprodutivo da expansão extensivo-intensiva da demanda}

Durante o Governo Lula, a produçáo nacional total, mais conhecida como produto interno bruto, ampliou-se a uma média de 4,055\% ao ano, o que, nos oito anos de governo, corresponde a uma expansáo total de, aproximadamente, $32,44 \%{ }^{5}$. Sem dúvida, esse é um dos fenômenos mais marcantes da gestáo, principalmente quando levamos em conta que ele ocorre após um longo período em que a economia vinha andando de lado e a estagnaçáo parecia ter se transformado num mal crônico: durante os anos 90, o crescimento médio anual foi de $1,6 \%$. Se ainda levarmos em conta que, nesse mesmo período, a taxa de desemprego passou de, aproximadamente, $6,8 \%$ para $10,5 \%$, vemos que, de fato, a situação econômica não era das melhores quando Lula assumiu o país. A questáo que se coloca entáo é por que, nesses oito anos, conseguiu-se sair da estagnaçáo, alcançando-se um ritmo de crescimento que, além de ser satisfatório, conseguiu arrastar a taxa de desemprego de 10,5\%,

5 Todos os dados econômicos aqui reproduzidos são informações do IPEA e estão disponíveis em: <www. Ipeadata.gou.br>. Acesso em: 12 jan. 2011. 
em dezembro de 2002, para 5,3\% em dezembro de 2010. Como já mencionei acima, acredito que a abordagem de Luxemburgo sobre o problema da reprodução pode ajudar bastante a compreender a bem sucedida alternativa lulista para o problema da acumulaçáo de capital, contudo, antes de colocar essa intervençáo sob a égide da abordagem de Luxemburgo, é preciso que façamos um breve repasse do histórico de sua gestáo econômica.

Lula iniciou seu governo sob o impacto do próprio processo eleitoral que o acabou levando ao Palácio do Planalto. Falo aqui do famoso "risco Lula", termo adotado entre alguns economistas e comentaristas políticos, que representava o temor do mercado sobre possíveis medidas que um candidato de esquerda poderia tomar caso viesse a ganhar a eleiçáo. Esse fato foi decisivo para a elaboraçáo da Carta aos brasileiros, na qual Lula assegurava que, caso ganhasse a disputa eleitoral, respeitaria os contratos nacionais e internacionais. Porém, se a carta ajudou Lula a vencer a eleição, não teve o mesmo efeito sobre a confiança do mercado, isso porque, além do "risco Lula", também havia o espectro da recente moratória argentina e os péssimos indicadores da economia nacional, que apresentavam uma queda na taxa crescimento, desemprego e intensivo aumento da dívida pública (duas vezes a média latino-americana). Assim, como afirma Perry Anderson, "aos olhos do mercado financeiro, o Brasil estava à beira do precipício" (ANDERSON, 2011, p. 1). No seu primeiro ano, portanto, o governo imprimiu uma política econômica voltada à recuperaçáo da credibilidade, a qual, naquele momento, dependia de um equilíbrio nas contas externas. Segundo Leda Maria Paulani, em seu incrível artigo Quando o medo vence a esperança, que se propóe a fazer um balanço da política econômica do primeiro ano do Governo Lula, as três variáveis que, na época, haviam sido entronadas como únicos indicadores de saúde econômica eram: o preço do dólar americano, a cotaçáo da C-bond (título da dívida brasileira negociado em mercados internacionais) e o risco-país (PAULANI, 2006, p. 12). Paulani afirma também que, ainda que a desconfiança fosse exagerada e decorrente do terrorismo eleitoral, essas variáveis encontravam-se, ao final de 2002, em níveis indesejados: "o dólar chegara a atingir R \$ 4,00 (fecha o ano a $\mathrm{R} \$ 3,50$ ), a cotaçáa do C-Bond ficara abaixo dos $50 \%$ do valor de face [quanto menor a credibilidade de um título, menor sua cotaçáo] e o risco Brasil alcançara 2000 pontos" (PAULANI, 2006, p. 12). O comportamento dessas três variáveis é influenciado pela perspectiva de uma inadimplência externa, ou seja, de que, em algum momento, o país náo disponha de dinheiro para 
arcar com seus compromissos, logo, a fim de que o "risco Lula" não agravasse ainda mais a já depreciada saúde da balança de pagamentos, era preciso recuperar a credibilidade. Para tal, acreditou-se, naquele momento, que o caminho mais seguro seria uma orientaçáo econômica ortodoxa, a qual, como havíamos aprendido com o governo de FHC, baseia-se na restriçáo das emissóes monetária, do investimento público e numa contração da liquidez pela elevação da taxa de juros. O primeiro ano do governo Lula, portanto, optou por "beijar a cruz" da ortodoxia ${ }^{6}$ e deu continuidade à política econômica de FHC.

Contudo, a cruz da ortodoxia era pesada demais para que pudesse ser carregada e, ao mesmo tempo, pudesse permitir a Lula cumprir duas de suas principais promessas eleitorais: criar dez milhóes de novos empregos e retirar o país da estagnaçáo econômica. Tal fato decorre de serem as medidas ortodoxas orientadas a um modelo de acumulaçáo de capital que náo depende da produçáo de mercadorias: o modelo de acumulaçáo rentista ou financeiro. Justificando-se no imperativo de combate à inflação e na necessidade assegurar a credibilidade necessária à entrada dos investimentos internacionais que resolveriam o problema de nossas contas externas, o modelo ortodoxo entrara no Brasil durante a gestão FHC e foi, disciplinadamente, seguido durante os oitos anos de governo. Tal modelo é baseado no Consenso de Washington, uma "receita", elaborada em 1989 por economistas do Fundo Monetário Internacional, do Banco Mundial e do Departamento de Tesouro Americano, para a promoção de ajustamento macroeconômico de "países em desenvolvimento com dificuldades". Consistia em políticas monetárias e fiscais rígidas, reduçáo do tamanho do Estado, abertura comercial, desregulamentaçáo da economia e taxas de juros reais elevadas. Sob a premissa de reduzir as pressóes inflacionárias, FHC aplicou as medidas de arrocho fiscal e de reduçáo de liquidez prescritas pela receita do Consenso: aumentou absurdamente as taxas de juros, cortou despesas públicas e aumentou todos os impostos em cinco pontos percentuais. Esses fatores, somados à abertura comercial, criaram um cenário tenebroso para qualquer um que almejasse fazer um investimento na produção nacional. Com a restriçáo do crédito, a elevaçáo dos impostos e a competiçáo dos produtos internacionais, nem o mais ousado dos burgueses

6 Expressão de Paulo Arantes, em seu artigo sobre o início do governo Lula, "Beijando a Cruz", Reportagem, $n$. 44. maio de 2003. 
se sentiria à vontade para aplicar seu capital privado na produçáo de mercadorias. E, se somamos a isso o fato de que o banco central emitia títulos que chegavam a pagar $50 \%$ de juros no médio prazo, fica bem claro que, dentro de tal modelo político-econômico, fica completamente inviável a expansáo do capital produtivo ${ }^{7}$.

Como vimos acima, a essência fenomenológica do investimento é a transformaçáo da forma monetário-universal do capital numa forma fixa, é a transformaçáo de dinheiro em bens voltados para a produçáa. Esse movimento produtivo, como também foi visto, é a fonte da mais-valia capitalista: ao vender as mercadorias, o empresário repóe seus gastos e ainda embolsa um excedente. Mas com a generosidade de um banco central que, durante os oito anos de governo, pagava, em média, 26\% de juros sobre seus títulos, produzir torna-se um fenômeno coadjuvante no esquema da mais-valia. Disso resulta que a receita do Consenso de Washington, adotada por FHC como soluçáo para o mal da inflação, era a de impor ao país um regime de acumulaçáo de capital rentista. $\mathrm{O}$ processo de financeirizaçáo do capital, globalmente em curso desde os anos 80, finalmente chegava ao Brasil. O legado da opçáo por esse modelo de acumulaçáo, além de uma estagnação produtiva, da retração do mercado interno e do aumento da fragilidade externa, foi um processo de transferência de renda da sociedade para a esfera financeira, já que é com o dinheiro da arrecadaçáo que o governo arca com suas dívidas, ou seja: quem trabalha "paga" o lucro de quem especula. Nos dois primeiros anos de seu governo, Lula conservara praticamente intacta a estrutura desse modelo de acumulação, que extraiu renda real da sociedade para engordar financeiramente os capitais, e manteve a economia nacional presa à "armadilha externa" (PAULANI, 2006, p. 23). Fica claro, entáo, que, mantido esse modelo, seria impossível expandir a economia e gerar empregos. A questáo que se coloca é: o que mudou?

Se, no primeiro ano do governo, os resultados econômicos foram desastrosos, com queda no consumo, aumento de desemprego e crescimento de míseros $1,1 \%$, as coisas começam a melhorar no segundo: ao final de 2004 , registrava-se um crescimento econômico de $5,7 \%$ e o início de uma melhora

7 A única possibilidade residia então no setor exportador, já que uma alta nos preços de suas mercadorias poderia vir a compensar as restrições internas. 
no nível de emprego. Contudo, tal salto náo refletia uma mudança nas condiçóes internas da economia; era essencialmente decorrente de uma expansão da demanda internacional, fundamentalmente chinesa, por produtos primários como soja e minério de ferro. No ano de 2004, houve um acréscimo de $34,65 \%$ no valor das exportaçóes de produtos primários, que passaram de, aproximadamente, 21 para 26 bilhóes de dólares. Vale salientar que, com a exceção do ano de 2009, essa expansáo foi constante até o final do segundo mandato de Lula, quando o valor das exportaçóes primárias atingiu 90 bilhóes de dólares. É provável que, não fosse tal expansão, a qual imediatamente se refletiu na arrecadaçáo do Estado, náo teria sido possível ao governo gastar com os programas socioeconômicos que marcaram o contexto reprodutivo do período. Com dinheiro em caixa, o governo, entáo, começou a intervir na sociedade ${ }^{8}$ : em 2004, a despesa orçamentária, excluída as transferências realizadas a estados, municípios e ao Distrito Federal e os pagamentos relativos à dívida pública, aumentou $14 \%{ }^{9}$. As condiçóes começavam, portanto, a ficar propícias para que Lula começasse a cumprir uma promessa de campanha que ainda não havia sido citada aqui, o combate à pobreza. No dia 6 de Janeiro de 2004, foi sancionada a Lei 10836, que cria o Bolsa Família, um programa federal de transferência direta de renda que, nesse mesmo ano, representou uma despesa de R \$ 5,5 bilhóes ao governo. Se a esse valor somam-se os $\mathrm{R} \$ 14$ bilhóes aplicados em 2005 e 2006, resulta que, só no primeiro mandato da gestáo, aproximadamente $\mathrm{R} \$ 20,5$ bilhóes foram injetados na economia somente através desse programa social. Durante todo o segundo mandato de Lula, os valores anualmente investidos no programa continuaram a crescer: R \$ 7,9 bilhóes em 2007, R \$ 10,5 bilhóes em 2008, R \$ 13,3 bilhóes em 2009 e $\mathrm{R} \$ 14$ bilhóes em 2010. Se somarmos esses gastos aos do primeiro mandato, resulta que mais de $\mathrm{R} \$ 66$ bilhóes foram diretamente transferidos àquelas famílias que náo dispunham de renda suficiente nem para suas necessidades

8 Todo dado aqui reproduzido sobre as despesas da União é do Tribunal de Contas da União e está disponivel em: <http://portal2.tcu.gou.br/portal/page/portal/TCU/comunidades/contas/contas_governo>. Acesso em: I3 jan.2012.

9 Na gestão de Lula, a taxa de investimento público saiu de I,5\% do PIB, um dos niveis mais baixos da história recente do país, para 2,9\% no final de 2010. Na gestão de FHC, esse valor caiu de aproximadamente 2,05\% para 1,5\%. Nota-se, assim, que a transição do periodo de queda real do investimento público (1995-2003) para um período de crescimento intenso deste (2004-20 I0) guarda relação com a aceleração da taxa de crescimento da economia. 
mais básicas. Para uma economia que, na década anterior, se habituara à estagnação, uma movimentação monetária de 66 bilhóes de reais não pode ser algo economicamente irrelevante. Os coraçóes burgueses, por mais que estivessem acomodados à acumulaçáo rentista, jamais se negariam a abandonar-se à sedução de tal disponibilidade monetária. E, como testemunha o progresso de aproximadamente $60 \%$, de 2003 a 2010, no índice de volume de vendas no varejo de produtos alimentícios, bebidas e fumo, tal disponibilizaçáo náo foi um fenômeno econômico irrelevante. Assim, a fim de que seja possível contribuir para a compreensáo da relevância econômica desse fenômeno, tentemos observar agora qual o significado reprodutivo desses $\mathrm{R} \$ 66$ bilhóes.

Para compreender a essência reprodutiva desta oferta monetária feita pelo governo Lula através do Bolsa Família, acredito que, de momento, devamos deixar de lado sua distribuiçáo quantitativa. $\mathrm{O}$ impacto econômico desses $\mathrm{R}$ \$ 66 bilhóes decorreu, principalmente, da natureza econômica dos seus beneficiários, os quais são indivíduos que náo estáo integrados, ou têm uma integraçáo marginal ao mercado capitalista. $\mathrm{O}$ que levaremos em conta aqui, portanto, é a composição qualitativa da demanda gerada por esses $\mathrm{R} \$ 66$ bilhóes. Devido à situaçáo de pobreza, toda quantia recebida por tais beneficiários se converte em consumo, isto é, todo volume monetário que o governo colocava em suas máos voltava na sua totalidade para o mercado. E o aumento no poder de compra desse setor social náo era decorrente da depreciaçáo na renda de outro, pois como vimos acima, foi a boa fortuna externa e não uma reforma fiscal que permitiu ao governo aumentar sua arrecadaçáo. Assim sendo, como os beneficiários do Bolsa Família não se constituíam como agentes imediatos da produçáo capitalista, esse dinheiro entra na economia quase que completamente sob a forma de renda nova. O bom momento do mercado internacional, portanto, ajudou o governo promover uma transferência de renda pacífica, que tocou justamente naquilo que Rosa Luxemburgo colocara como "ponto nevrálgico da acumulação" (LUXEMBURGO, 1988b, p. 19), qual seja: a necessidade de "terceiras pessoas", de outros consumidores além dos agentes imediatos da produçáo capitalista. Em 2003, 50,99\% da população brasileira, isto é, aproximadamente 87 milhóes de pessoas, viviam em situaçáo de miséria e pobreza, o que significa que sua renda náo pagava nem uma cesta de alimentos com o mínimo calórico necessário. Não é difícil de perceber que esses 87 milhóes de pessoas viviam uma integração marginal 
ao modo de produçáo capitalista, pois produzir suas condiçôes de vida dentro deste, quando não se possui nenhum meio de produçáo, significa materializar sua força de trabalho como mercadoria, o que, por conseguinte, significa para o trabalhador ter garantido o valor de sua contínua subsistência. É mais que sabido que a informalidade e o desemprego estrutural são fatores que, historicamente, marcam o mercado de trabalho brasileiro. A evoluçáo do trabalho como mercadoria na sociedade brasileira é bastante precária, algo que, em seu livro Sociedade de classes e subdesenvolvimento, publicado em 1968, já apontava Florestan Fernandes (FERNANDES, 2011, p. 46). Assim, esses 87 milhóes de indivíduos produziam sua subsistência através de uma integraçáo marginal ao sistema capitalista de produçáo. Sua precária vitalidade se vinculava às mais variadas práticas de subsistência urbana e rural, dentre as quais podemos pensar na esmola, no comércio informal, no trabalho análogo ao escravo, no artesanato, na agricultura de subsistência e na pesca, por exemplo. A obra de Josué de Castro tem muito a dizer sobre a forma de vida desses marginais históricos do desenvolvimento nacional do capitalismo ${ }^{10}$. Tais indivíduos eram, portanto, uma camada social que vivia inserida numa dinâmica produtiva semi ou náo capitalista, muitas vezes sequer entrando no circuito de trocas. Assim, em termos de reproduçáo produtiva, o que o programa Bolsa Família fez foi criar uma procura monetária que, além de estar imediatamente disposta a consumir, era completamente nova, pois deu àqueles que se enquadravam nos critérios do benefício uma fonte extra de renda até então inédita, o que motivou os produtores a acumular capital e expandir sua produçáo ${ }^{11}$. Náo custa lembrar, mais uma vez, que o problema da demanda é o fundamento da expansão capitalista, "não se produz capital constante [isto é, não se faz um investimento] simplesmente por produzi-lo, mas para empregá-lo nas esferas de produção voltadas para o consumo individual" (MARX apud LÊNIN, 1982, p. 24). O que se observa, portanto, é que o diferencial reprodutivo da oferta monetária

10 "Eram retirantes de outras secas, tangidos pelo vento de fogo do sertão, como um monturo humano. Eram emigrantes expulsos do outro latifúndio - o do açúcar - , este bem mais protegido pela lei, onde não podia haver invasões de terras. O que havia era o regime do arrocho, do trabalho esfalfante no eito da cana, sem tempo nem permissão para se plantar um pé de milho ou de feijão para ajudar a matar. E assim, o latifúndio do açúcar secretava sempre seus excessos de gente que o latifúndio da lama absorvia como um mata-borrão. E a cidade do Recife inchava, embebida daquela tinta grossa de miséria formando sua crosta de mocambos." (CASTRO, 200I, p. 106)

II Uma referência nesse sentido é o texto do economista Marcelo Neri, A Nova Classe Média: o lado brilhante da pobreza, publicado no final de 2010. 
criada pelo Bolsa Família é sua imediata disponibilidade ao consumo e sua exterioridade do fluxo regular de procura. A quantia de $\mathrm{R} \$ 66$ bilhóes entra na economia como demanda excedente, como novíssimo poder de compra, o que, desse modo, a faz preencher o critério defendido por Luxemburgo como soluçáo para o problema da reproduçáo. Os novos consumidores, que, segundo Luxemburgo, a Europa conseguiu através do imperialismo, num país subdesenvolvido como o Brasil, onde há uma integração precária de diversos estratos da população com a produção capitalista, apareceram através de uma política social. Não estou aqui querendo dizer que o setor informal náo fosse parte estruturante do capitalismo brasileiro, ou seja, que ele estivesse "fora" da dinâmica interna do sistema, mas apenas destacando a oportunidade que a forma particular de integração desse setor ao sistema (aliada a superávits comerciais robustos e a uma deliberada política de distribuiçáo de renda) ofereceu em termos de reproduçáo do capital social total. Como foi repetidamente exposto na primeira seçâo deste texto, a acumulação de capital (ou o investimento) requer uma demanda extra para que possa se materializar, pois se as novas mercadorias não sáo trocadas por dinheiro, a finalidade da produçáo capitalista perde seu sentido, logo, o grande efeito do Bolsa Família foi expor ao capital que há uma larga disponibilidade de "meios" através dos quais este pode expansivamente reproduzir-se no Brasil.

O Bolsa Família é, portanto, uma política de fomento da renda nacional, o que não é novidade na história econômica do Brasil, vide, por exemplo, a política de defesa do Café dos anos 30, quando o Estado comprava café com o fim de manter seu preço e, assim, evitar uma contraçáo na renda monetária do produtores (FURTADO, 2009, p. 269). Contudo, o diferencial da experiência de fomento promovida pelo Bolsa Família é sua via de entrada para a sociedade: um contingente populacional excluído do processo produtivo cuja capacidade de consumo era praticamente nula. É política de combate à pobreza ao mesmo tempo em que é política de transferência de renda. Através desses outsiders, esse programa garantiu que os meios monetários aplicados apresentassem um retorno líquido como demanda efetiva. De janeiro de 2004 a dezembro de 2010, náo há um mês sequer em que o percentual de vendas no varejo não haja aumentado em relaçáo ao mesmo mês do ano anterior. É, portanto, por vir, paulatinamente, agregando novas camadas sociais ao processo de troca mercantil que o programa Bolsa Família permitiu a ampliação da produção capitalista e, assim, pode ser compreendido como uma soluçáo econômica 
para o problema da reprodução. Proponho, portanto, que esse programa seja compreendido como uma política extensiva de expansáo da demanda. Contudo, a recuperaçáo da economia náo está atrelada apenas a essa forma extensiva de intervençáo governamental. Se a oferta de poder de compra aos outsiders foi o motor de uma pressáo dinâmica sobre o mercado interno, que contribuiu para a ampliaçáo da produçáo tanto do setor de bens de consumo quando dos insumos a este relacionado, a magnitude dos resultados obtidos náo pode estar atrelada apenas a esses $\mathrm{R} \$ 66$ bilhóes. $\mathrm{O}$ aumento do poder de compra do mercado brasileiro náo se deve apenas a essa experiência extensiva, mas também a um processo intensivo de expansáo da demanda, o qual está fundamentalmente vinculado à política de valorização do salário mínimo. Reflitamos, entáo, como a valorização no salário mínimo pode impactar as condiçôes de reprodução, ou, mais precisamente, a acumulaçáo do capital.

De dezembro de 2002 a dezembro de 2010, o salário mínimo teve uma valorizaçáo real de aproximadamente $62,5 \%$. O primeiro impacto reprodutivo dessa política de valorizaçáo pode ser observado pelo aumento nas contas da previdência: segundo o Departamento Intersindical de Estatística e Estudos Econômicos (DIEESE), o acréscimo de cada R \$ 1,00 no salário mínimo tem um impacto estimado de R \$ 257 milhóes ao ano sobre a folha de beneficiários da Previdência Social. De 2007 a 2010, a magnitude dos benefícios dessa instituição passou de R $\$ 185$ bilhóes para R $\$ 254$ bilhóes. A valorizaçáo do mínimo, portanto, levando em conta aqui apenas a perspectiva dos impactos que tem sobre as contas da Previdência Social, consiste, tal como o programa Bolsa Família, numa política de fomento da renda nacional. A elevaçáo do mínimo acarreta um aumento no poder de compra daqueles que têm seus benefícios previdenciários atrelados a esse valor, o que, segundo o DIEESE, equivale a 68,3\% dos beneficiários (DIEESE, 2011, p. 5). Tal qual no programa Bolsa Família, o governo gasta suas receitas para adicionar poder de compra ao mercado e promover a procura efetiva. E o que é relativo do ponto de vista da reproduçáo é que o potencial que essa valorizaçáo tem para se traduzir em consumo é quase idêntico ao do Bolsa Família, alterando-se apenas o enfoque da procura, a qual apresenta aqui um potencial maior para se traduzir em bens de consumo duráveis e serviços. Assim, os benefícios previdenciários decorrentes da valorização do mínimo também se traduzem numa procura efetiva, o que, como bem sabemos, é o motor do movimento de reprodução ampliada levado a cabo pelos 
produtores. Com seu impacto nos gastos da Previdência Social, portanto, podemos observar o primeiro lado daquilo que seria um processo intensivo de expansão da demanda desencadeado pela valorizaçáo do mínimo, e, nesse sentido, depois de tudo que foi discutido aqui, parece que fica claro seu impacto na dinâmica da acumulaçáo. $\mathrm{O}$ outro lado desse processo intensivo pode ser observado dentro da própria relação de produção capitalista, na qual, com a valorizaçáo do salário mínimo, a força de trabalho passa a se apoderar de uma parcela maior do valor produzido.

Já foi observado acima que a essência da relação capitalista de produção é a apresentação da força de trabalho como algo vendável, ou seja, que o empresário possa se relacionar com o trabalhador como se ele fosse uma mercadoria. O cálculo do preço do trabalho é feito sobre o custo da reposiçáo vital do trabalhador e náo sobre a magnitude de sua produção. Foi a compreensão desse fenômeno que levou Marx a perceber que o valor excedente ou a mais-valia decorrente do processo de produçáo capitalista náo deriva dos objetos envolvidos no processo, ou, como ele denominou, do capital constante, mas sim do fator subjetivo, do consumo da mercadoria trabalho. A taxa de mais-valia é justamente essa relaçáo entre o valor de troca do trabalho e seu valor de uso, entre salário e exteriorizaçáo produtiva líquida, entre trabalho pago e não pago (MARX, 2011, p. 253-254). É daí que resulta a famosa fórmula da composiçáo do valor da mercadoria: $c+v+m$, onde $c$ representa o capital constante gasto, ou seja, a parte correspondente aos meios de produçáo inanimados do processo; $v$ representa o capital variável, isto é, a parte gasta em salários; e $m$ a mais-valia, que representa o acréscimo de valor resultante da parte não paga ao trabalhador. Uma valorizaçáo do salário mínimo, que consiste num maior reconhecimento do valor de uso do trabalho, acarretaria uma depreciação da participação de $m$ e um fortalecimento na participaçáo de $v$ na composiçáo do valor, o que, a princípio, pode parecer uma contradiçáo com vocaçáo burguesa de acumular. Contudo, como havíamos dito antes, se pensarmos em termos de reproduçáo da produçáo do capital social total, o que acontece quando se transforma um pedaço da mais-valia em capital variável é a passagem de uma forma ociosa de valor para uma forma dinâmica, o que tem um impacto do ponto de vista reprodutivo. É uma quantidade de poder aquisitivo que, ao mudar de máos, muda também de potencial reprodutivo, pois a propensáo do trabalhador a aplicar esse dinheiro no consumo é muito maior que a do burguês, 
ainda mais na atual conjuntura do sistema financeiro internacional. E o potencial reprodutivo, isto é, a procura efetiva, é tudo que almeja um burguês para poder acumular capital e, assim, aumentar a extensáo da realizaçáo do seu lucro. Desse modo, essa pequena concessáo que a burguesia faz ao trabalho acaba por metamorfosear-se num investimento, pois, em médio prazo, garante a expansáo de suas forças produtivas e seu consequente desenvolvimento histórico. Evitando-se as pressóes inflacionárias e as tendências autoritárias de uma burguesia retrógrada ${ }^{12}$, o aumento do salário mínimo pode vir a ser um veículo de desenvolvimento da acumulação. E, segundo aponta o Comunicado IPEA ñ 155, intitulado A década inclusiva (2001-2011): Desigualdade, pobreza e políticas de renda (2012), foi o trabalho a principal fonte do crescimento real de quase $4,5 \%$ ao ano da renda individual durante o Governo Lula.

A fim de concluir esta já cansativa seção do texto, façamos algumas últimas consideraçóes. Tentou-se expor como, a partir de uma política extensiva e intensiva de ampliaçáo da demanda efetiva, através do programa Bolsa Família e da política de valorizaçáo do salário mínimo, respectivamente, o Governo Lula criou o terreno que permitiu à produçáo capitalista acumular capital e, assim, ampliar sua produçáo. Essas duas frentes de atuaçáo lulista criaram pressóes dinâmicas que atacaram aquilo que, para Rosa Luxemburgo, é o ponto nevrálgico da reproduçáo no capitalismo: uma procura monetária excedente capaz de realizar o mais-produto decorrente da acumulaçáo de capital. A disponibilidade da procura efetiva, somada ao barateamento do crédito e ao bom momento da economia internacional, criou, dentro da economia brasileira, uma nova alternativa de acumulaçáo de capital, que, ao contrário daquela posta em vigor pelo modelo ortodoxo, volta-se para a produçáo de mercadorias, isto é, de riqueza real. E uma ampliaçáo da produçáo de riqueza real só é possível na medida em que se amplia também a força de trabalho envolvida na produçáo, logo, o aumento do nível de emprego é sua consequência direta. E a consequência imediata de um aumento no nível de emprego é, logicamente, um crescimento da procura efetiva, que reinicia o ciclo. Enquanto os níveis de procura efetiva de uma sociedade se mantiverem crescentes, e o mercado

12 Essa versão burguesa é comum em países subdesenvolvidos, onde a acumulação capitalista reside numa burguesia agroexportadora articulada com os interesses do mercado internacional. Quaisquer tendências à ruptura dessa articulação, que garantem os ganhos da burguesia local, como, por exemplo, as que decorrem de um crescimento do setor manufatureiro voltado para o mercado interno, podem ser vistas como ameaças ao seu dominio. Sobre isso, ver A Revolução Burguesa do Brasil (FERNANDES, 2009, p. 34I). 
se mantiver protegido da concorrência internacional, o ciclo de crescimento sua economia possivelmente se manterá ininterrupto. E acredito que esse ciclo de crescimento econômico e geração de empregos, que, sem dúvida é o grande legado econômico de Lula, entra em vigor, fundamentalmente, graças ao significado reprodutivo das medidas de transferência de renda. Sua opçáo por utilizar o Estado para direcionar a renda no sentido das camadas menos favorecidas da sociedade criou condiçóes propícias à reprodução. As intervençóes sociais do governo, portanto, podem, imediatamente, ser consideradas também como politicas reprodutivas, pois fomentaram aquele "mercado suplementar" que Luxemburgo coloca como fundamental, não só à acumulaçáo de capital, mas também ao desenvolvimento histórico do capitalismo (LUXEMBURGO, 1988b, p. 127).

\section{0 significado moral da reprodução}

Viu-se, a partir da abordagem de Luxemburgo sobre problema da reprodução, que à expansão das forças produtivas é fundamental uma crescente disponibilidade do consumo. Segundo essa autora, os capitalistas e os trabalhadores constituem um mercado que, mesmo crescendo sem parar, sozinho não é capaz de absorver os produtos decorrentes de uma ampliaçáo constante da produção. Essa produção, então, é obrigada a buscar um mercado adicional, fora de seu ambiente regular, pois, para que a finalidade da produçáo capitalista, o lucro, se realize cada vez com mais vigor, é preciso vender cada vez mais mercadorias. A acumulaçáo progride, nesse sentido, aos meios sociais constituídos por formaçóes pré-capitalistas, inserindo-as na dinâmica mercantil, e, segundo Luxemburgo, essa integração representa o processo histórico real de desenvolvimento do capitalismo: "como processo histórico, a acumulaçáo do capital progride do princípio ao fim em um meio constituído por formaçóes pré-capitalistas várias, e em confronto político constante, mantendo intercâmbio econômico intermitente com as mesmas" (LUXEMBURGO, 1988b, p. 115). As formaçôes sociais não capitalistas ou semicapitalistas são, portanto, o meio histórico do desenvolvimento do capitalismo, pois é destas que deriva a nova demanda que permite ao capitalista acumular capital e, assim, ampliar sua obtenção de mais-valia. Essa decomposição das condiçóes não capitalistas de produçáo é a essência do imperialismo, o qual, segundo a autora, "náo passa, empiricamente, de um método específico de acumulaçáo" (LUXEMBURGO, 1988b, p. 114). Por mais que, para a autora, que vivia a 
euforia neocolonialista que antecedera a primeira guerra, o conceito de imperialismo esteja atrelado aos meios através dos quais este se desenvolvia naquele momento, como o militarismo e o colonialismo, sua essência teleológica é a expansáo do mercado capitalista mediante a integraçáo de modos de produçáo "pré-capitalistas". Como já vimos, acima, no Brasil que entra no século XXI, há 87 milhóes de pessoas em situaçáo de pobreza ou pobreza extrema, ou seja, pessoas que não obtinham sequer a reposiçáo da sua subsistência como resultado do seu trabalho, o que, desde o quarto capítulo do primeiro volume do Capital, é sabido ser o preço do trabalho quando este se realiza através de uma relaçáo capitalista de produçáo. Como expóe Florestan Fernandes, nesse setor social, onde prevalecem economias de subsistência e formas parcialmente mercantis de relaçáo de trabalho, o trabalho assalariado é visto como um privilégio social (FERNANDES, 2008, p. 46). Assim, partindo do conceito de imperialismo de Luxemburgo, podemos afirmar que esses 87 milhóes de indivíduos, marginalizados ou parcialmente integrados aos benéficos da racionalidade das trocas, constituíam um campo fértil para a expansáo da acumulaçáo capitalista. Contudo, o meio de sua inserçáo, ao contrário do que estava em voga no início do século, não foi violento, mas deu-se através de políticas públicas de transferência de renda. Na medida em que essas políticas de transferência de renda, aliadas com os investimentos públicos e a diminuição nas taxas de juros, vão acarretando um aquecimento do mercado interno e uma expansão da produção, alguns desses indivíduos excluídos, que se integravam marginalmente, muitas vezes apenas para matar sua fome, passam a ser convocados para atuar como força de trabalho. É como se as políticas de transferência de renda tivessem desencadeado um fenômeno de auto-imperialismo, pois trata-se de um processo de expansão demográfica do modo de produçáo capitalista que náo decorre da relação entre duas naçóes diferentes. Contudo, o processo de expansão do modo de produção capitalista dentro da sociedade brasileira náo pode ter apenas os reflexos econômicos que até aqui foram observados, tais como o aumento na taxa de acumulação de capital e no nível de emprego. Sem dúvida, uma mudança econômica do porte da que estamos atravessando náo deixará imune o ambiente ideológico no qual flutua o imaginário social. Passemos, então, a essa rapidíssima reflexão, puramente interpretativa, sobre um possível impacto ideológico do processo acima apresentado. 
A ideia central desta seção do texto é a de que a expansão do trabalho assalariado, ou melhor, a expansão da forma mercantil como meio de veiculaçáo do trabalho tem um impacto direto sobre a organizaçáo do pensamento individual. Como defende Mikhail Bakhtin, em harmonia com os princípios da lógica dialética, o pensamento individual não pode operar no vazio, isto é, não pode manifestar-se caso náo encontre um veículo que possa lhe dar forma. A consciência, portanto, precisa de um meio para desenvolver-se, precisa de um instrumento que lhe permita veicular-se e, assim, ganhar forma definida. Para Bakhtin, esse instrumento que dá forma ao pensamento é a linguagem, é através dela que se dá toda criação ideológica, seja ela qual for (BAKHTIN, 1992, p. 37). A consciência individual, para esse autor, náo poderia se desenvolver caso não dispusesse desse material flexível e veiculável que é o signo ou a palavra. O signo é o meio de toda ideologia. Assim, o que desejo aqui é introduzir uma reflexão sobre como a expansão do trabalho como forma mercantil pode estar impactando a disponibilidade desses signos, que, como defende Bakhtin, sáo o meio para o desenvolvimento do pensamento. A questáo central, portanto, é: qual o impacto da mercantilizaçáo do trabalho sobre a constituiçáo semiológica da consciência?

Acredito, entáo, que, para responder a essa questáo, precisemos nos remeter mais uma vez a Marx, pois foi aquele que, com maior precisáo, conseguiu expor a totalidade dos impactos ontológicos dos conceitos que orientam o trabalho no capitalismo, porque compreendeu, na contramão do materialismo vulgar, que a conversão da natureza em coisas úteis pelo trabalho é também um processo ideológico, e náo puramente material. Isso o levou a perceber aquilo que, de fato, interessa nesta última seção do texto: que os efeitos do trabalho náo se manifestam apenas nas coisas, mas também nas pessoas. Assim, a compreensão do trabalho como um processo ideal é a chave para a identificaçáo do significado ontológico de sua teleologia. É essa compreensáo que leva Marx a afirmar que, no capitalismo: "o trabalho náo produz somente mercadorias; ele produz a si mesmo e ao trabalhador como uma mercadoria, e isto na medida em que produz, de fato, mercadorias em geral" (MARX, 2009, p. 80). Assim, a fim de que compreendamos tanto como o trabalho se manifesta enquanto processo ideológico quanto qual é o resultado semiológico desse processo quando orientado pela predominantemente pelos conceitos do modo de produçáo capitalista, sugiro que voltemos ao quarto capítulo do pri- 
meiro volume do Capital, no qual Marx teoriza sobre o "processo de trabalho" e o "processo de produzir mais-valia".

Para Marx, "antes de tudo, o trabalho é um processo de que participam o homem e a natureza, processo em que o ser humano, com sua própria açáo, impulsiona, regula e controla seu intercâmbio material com a natureza” (MARX, 2011, p. 211). É, portanto, um esforço físico feito pelo ser humano a fim de apropriar-se dos recursos da natureza e imprimir-lhes uma forma útil à sua vida. Contudo, enquanto apropriação da natureza, o trabalho humano em nada se distingue do de qualquer outro animal, o que marca a diferença do trabalho humano e "[...] distingue o pior arquiteto da melhor abelha é quee ele figura na mente sua construção antes de transformá-la em realidade" (MARX, 2011, p. 211-212). Ao contrário do que acontece com um animal, que trabalha instintivamente, ao final de um processo de trabalho humano, aparece um resultado que antes já existia idealmente na consciência do trabalhador. $\mathrm{O}$ que, portanto, para esse pensador, marca o trabalho humano é a finalidade, a antecipação ideal de um fim ao processo efetivo. Não há trabalho humano que, antecipadamente, já não tenha conscientemente uma finalidade definida. Dentro do processo de trabalho se manifesta a subordinação, tanto da vontade individual quanto do modo de operar, ao projeto daquilo que, ao final, se almeja lograr. Assim, o trabalho humano “[...] náo transforma apenas o material sobre o qual opera; ele imprime ao material o projeto que tinha conscientemente em mira, o qual constitui a lei determinante do seu modo de operar e ao qual tem que subordinar sua vontade" (MARX, 2011, p. 212). Daí se pode concluir que, quando inserido numa dinâmica produtiva, o ser humano subordina sua vontade e seu modo de operar a uma determinada ideia, seja ela um alimento, uma obra de arte ou uma ferramenta, por exemplo. Penso, portanto, ser bastante acertada a afirmaçáo de Slavoj Zizek de que "o nível fundamental da ideologia náo é o de uma ilusão que mascare o verdadeiro estado de coisas, mas de uma fantasia que estrutura nossa própria realidade" (ZIZEK, 2010, p. 316). O fim do trabalho, portanto, é uma ideia, é ela que leva o ser humano a utilizar sua força de uma determinada maneira para dar nova forma a um objeto bruto, e, dependendo de qual seja essa ideia, muda-se tanto a maneira com que a força é utilizada quanto o objeto que lhe serve de base à transformaçáo. Que fique claro que aqui náo me interessa 
defender que o processo de trabalho seja reduzível a uma ideia, mas apenas enfatizar que este último, enquanto ação humana, é um processo material no qual está irremediavelmente envolvido um elemento semiológico, pois não há trabalho humano que náo tenha um significado conceitual específico a determinar tanto sua forma de implementaçáo como a de seu objeto. Não fosse essa fundamentação sócio-conceitual do trabalho, o modo de produção humano não variaria historicamente e ainda estaríamos submetidos à dinâmica autoprodutiva da natureza.

$\mathrm{Na}$ forma histórica do capitalismo, como vimos acima, a finalidade da produçáo é o valor. É o dinheiro o objetivo final ou a ideia que justifica todo o circuito produtivo. $\mathrm{E}$ o dinheiro não é apenas a finalidade do produtor capitalista, proprietário dos meios de produção. É também essa ideia que leva aqueles que náo possuem meios de produçáo a abandonarem qualquer outra tentativa de subsistência e se oferecer como mercadoria a ser consumida pelos capitalistas. Defendo aqui, que tal auto-oferta como mercadoria é, portanto, o significado conceitual fundamental que orienta o trabalho capitalista, pois expressa a consequência antropológica de se optar por colocar o dinheiro como fim da produçáo numa sociedade pautada pela propriedade privada dos meios produtivos. A forma-mercadoria é o status ontológico imediato que decorre do fato de o trabalhador, desprovido de meios de produçáo, organizar o pensamento a partir da ideia do valor. A ideia do valor é o esteio da realidade da forma-mercadoria (ZIZEK, 2010, p. 324-325). O trabalho, portanto, quando inserido nas condiçóes históricas do modo de produçáo capitalista, tende a subordinar a vontade individual à ideia do valor, logo, na medida em que a mercantilizaçáo do trabalho se expande dentro de uma sociedade, mais intensiva se torna a presença ideológica do dinheiro. Penso, portanto, que uma consequência da expansão do trabalho mercantil, é a expansão moral da ideia que define a sua orientaçáo teleológica: o signo do valor.

Respondendo, por conseguinte, à questáo formulada no início desta seçáo, afirmo que seja a impregnação do ideal monetário um possível impacto da mercantilizaçáo do trabalho sobre a constituiçáo semiótica da consciência dos brasileiros. Com a atual expansáo intensiva e extensiva do mercado capitalista dentro da sociedade brasileira, acredito ser possível afirmar que nunca o ideal monetário exerceu tanta pressáo sobre a organizaçáo do pensamento das pessoas. O impacto de tal territorializaçáo do trabalho mercantil ganha 
uma maior ênfase cultural se, além dessa expansáo do capitalismo, levarmos em consideraçáo a precariedade do sistema nacional de educaçáo e dos meios de comunicaçáo de massa. Pode-se deduzir, portanto, que, numa conjuntura de expansáo do trabalho mercantil, aliada a uma precariedade do sistema de ensino, ao avanço moral do valor semiológico do dinheiro, náo se apresentam muitas opçóes de resistência.

Defendo aqui que, durante a gestáo do presidente Lula, pouco foi feito para fortalecer a principal frente não mercantil de veiculaçáo ideológica ou de organizaçáo do pensamento, que é a escola. Apesar do êxito na expansáo do acesso à educação primária ${ }^{13}$, a qual, segundo a Organizaçáo das Nações Unidas para a Educação, Ciência e Cultura (UNESCO), consiste na oferta de uma base sólida de leitura, escrita e matemática, e que passou a contemplar $97 \%$ da população nacional em $2007^{14}$, e do avanço no número de matrículas no ensino superior, que passou de 2,4 milhóes de alunos matriculados, em 1999, para 5,2 milhóes em 2007, o grau de desenvolvimento da educação avançou pouco no país durante o Governo Lula. Em 2008, da populaçáo com 18 anos de idade, apenas 75,2\% havia concluído o ensino fundamental, etapa que deve ser terminada até os 15 anos. Especialmente aquém de níveis satisfatórios encontra-se a situaçáo do ensino médio. Em 2008, o número de matrículas no ensino médio regular era ligeiramente inferior àquela que existia no ano de 2001; passou-se de um contingente de 8,398 milhóes de jovens matriculados para 8,366 milhóes. O monitoramento da UNESCO também aponta progressos espúrios no desenvolvimento da educaçáo infantil e da alfabetização de adultos, com avanços, no nível de abrangência demográfica, de aproximadamente 7,6 e 2,4 \%, respectivamente. Por mais que dentro da estrutura de ensino brasileira estejam os níveis fundamental e médio, em sua maioria, sob responsabilidade dos estados e municípios, sem dúvida é possível afirmar que a educaçáo não foi uma prioridade da gestão do presidente Lula. Com exceçáo da Lei No 11738, de 16 de julho de 2008, que determina um piso nacional para o magistério público da educação básica e seu reajuste anual, e do investimento no ensino superior, pouco foi feito pelo governo federal,

13 A categoria de educação primaria é utilizada pela UNESCO e, dentro da terminologia referente à estrutura de ensino brasileira, corresponde à última série da educação infantil mais as quatro primeiras séries $\left(1^{a}\right.$ à $4^{a}$ séries) do ensino fundamental.

14 Todo dado aqui reproduzido sobre os resultados da política educacional do Governo Lula foi retirado do Monitoramento de educação para todos, divulgado no começo de 2010 pela UNESCO e está disponível em: <http://unesdoc.unesco.org/images/0018/001899/189923por.pdf>. Acesso em: 22 mar. 2012. 
de 2003 a 2010, para fortalecer a influência do ensino na formaçáo semiológica dos indivíduos e, assim, solidificar a educação como elemento cultural constitutivo da sociedade brasileira.

Nesse sentido, acredito ser possível afirmar que este é o segundo dogma da gestáo de Lula: o livre desenvolvimento do ideário mercantil-monetário. Este estudo introdutório náo almeja nem pode se aprofundar nas consequências culturais do avanço desse significado semiológico na sociedade brasileira, o que sem dúvida carece de um estudo mais cuidadoso. Uma possível consequência desse processo de territorialização semiológica do trabalho mercantil, que, irresponsavelmente, poderia ser mencionada aqui, é, por exemplo, o recrudescimento da utopia antropofágica, na medida em que o movimento cultural por ela defendido é um movimento de síntese. Tanto para o próprio Oswald de Andrade quanto para as manifestaçóes culturais brasileiras que reivindicaram essa utopia, como o tropicalismo e o movimento mangue, por exemplo, essa síntese se manifestava entre o local e o global. Contudo, nas camadas sociais locais, a perpetuação de seu repertório cultural específico estava ligada a modos de produçáo semi ou náo capitalistas, os quais, com a expansão da acumulaçáo de capital, tendem a se desagregar. Mantidos o inerte desenvolvimento do sistema de ensino nacional e a precariedade ideológica dos meios de comunicaçáo, é possível que o atual desenvolvimento da acumulação venha a desencadear a plena sedimentaçáo da cultura industrializada, tal qual fora teorizada por Theodor Adorno e Max Horkheimer, em que "as particularidades do eu são mercadorias monopolizadas e socialmente condicionadas que se fazem passar por algo natural" (ADORNO; HORKHEIMER, 2006, p. 128).

Náo pretendo aqui afirmar que esse seja um processo em curso, mas apenas apontar, partindo da teoria de Rosa Luxemburgo sobre a acumulaçáo de capital e das observaçóes feitas aqui sobre o atual desenvolvimento do capitalismo no Brasil, a deterioraçáo das condiçóes de realizaçáo da utopia antropofágica em prol de uma universalização do ideal monetário como uma possível tendência. Contudo, a fim de que se possa compreender as empíricas consequências culturais da territorialização da forma mercantil de trabalho decorrentes da gestáo de Lula, faz-se necessário um estudo mais cauteloso.

\section{Referências}

ADORNO, T.; HORKHEIMER, M. Dialética do Esclarecimento. Rio de Janeiro: Jorge Zahar, 2006. 
ALTHUSSER, L. Sobre a reproduçáo. Rio de Janeiro: Vozes, 2008.

ANDERSON, P. Lula’s Brazil. London Review of Books, Londres, v. 31, 2011.

BAKHTIN, M. Marxismo e Filosofia da Linguagem. Sáo Paulo: Hucitec, 1992.

CASTRO, J. Homens e Caranguejos. Rio de Janeiro: Civilizaçáo Brasileira, 2001.

DIEESE. Política de valorizaçáo do mínimo: consideraçóes sobre o valor a vigorar a partir de $1^{\circ}$ de janeiro de 2012. Nota Técnica, Rio de Janeiro, n. 106, 2011.

FERNANDES, F. Sociedade de classes e subdesenvolvimento. Sáo Paulo: Global, 2011.

A revoluçáo burguesa no Brasil. Sáo Paulo: Globo, 2009.

FURTADO, C. Formaçáo Econômica do Brasil. São Paulo: Companhia das Letras, 2009.

IPEA. Comunicado IPEA no 155: A década inclusiva (2001-2011): Desigualdade, pobreza e políticas de renda. Brasília: IPEA, set. 2012.

LÊNIN, Vladimir. O desenvolvimento do capitalismo na Rússia. São Paulo: Abril cultural, 1982.

LUXEMBURGO, R. A Acumulaçáo do Capital. Sáo Paulo: Nova Cultural, 1988a, v. 1.

A Acumulaçáo do Capital. São Paulo: Nova Cultural, 1988b, v. 2.

MARX, K. O Capital. Rio de Janeiro: Civilizaçáo Brasileira, 1980. v. 2.

Manuscritos econômico-filosóficos. São Paulo: Boitempo, 2009.

O Capital. Rio de Janeiro: Civilização Brasileira, 2011. v. 1.

PAULANI, L. M. Quando o medo vence a esperança. Crítica Marxista, Campinas, v. 19, p. 11-25, 2006.

SAVIANI, D. Pedagogia histórico-crítica. São Paulo: Cortez, 1991.

SMITH, A. Investigaçáo sobre a natureza e as causas da riqueza das naçóes. Sáo Paulo: Abril Cultural, 1974.

ZIZEK, S. Um Mapa da Ideologia. Rio de Janeiro: Contraponto, 2010.

Data de recebimento: $23 / 03 / 2012$

Data de aprovação: 15/10/2013 


\section{Two dogmas of "Lulismo"}

\section{Abstract}

I argue here that president's Lula administration was socio-economically conditioned by two dogmas. One was the extensive and intensive growth of effective demand, implemented mainly through the Bolsa Familia program and the real appreciation of the minimum wage. And the other, an openness for the free development of market ideology. The text is divided into three sections. At first, I make a brief presentation of the theoretical framework to guide the analysis of Lula's government: Rosa Luxemburg's reproduction theory, exposed in her work The Accumulation of Capital. In the second I intent to analyze, from the perspective of reproduction theory, Lula's capital accumulation model. And finally, in the third, I try to point out some possible impacts of this ideological model.

Keywords: Reproduction. Accumulation. Commodity. Development. Labor. 